\title{
AN INDIRECT ACTION OF DOPAMINE ON THE RAT FUNDUS STRIP MEDIATED BY 5-HYDROXYTRYPTAMINE
}

\author{
P. F. SONNEVILLE \\ Department of Pharmacology, Medical Faculty, \\ University of Utrecht, Vondellaan 6, Utrecht, The Netherlands
}

A ccepted 29 January 1968

\begin{abstract}
P. F. SONNEVILLE, An indirect action of dopamine on the rat fundus strip mediated by 5-hydroxytrytamine, European J. Pharmacol. 2 (1968) 367-370.

Dopamine in a concentration of $10^{-7}$ molar produces a contraction of the rat stomach fundus preparation. This effect is blocked by the 5-HT antagonist methysergide. Repeated exposure to dopamine results in tachyphylaxis, but the sensitivity to dopamine can be restored by incubating the tissue with 5-HT. The results are interpreted as indicating that dopamine releases 5-HT.
\end{abstract}

Dopamine
5-HT
UML

\section{INTRODU CTION}

The actions of dopamine can be attributed partly to $\alpha$-adrenergic stimulation and partly to $\beta$-adrenergic stimulation, although several authors have suggested the existence of another receptor for this amine (Goldberg and Sjoerdsma, 1959; McDonald and Goldberg, 1963; Eble, 1964; Van Rossum, 1964; Ernst, 1965). So far no simple organ system is known which indicates stimulation of another dopamine receptor. How ever, in the rat stomach preparation, dopamine showed an activity which could not be ascribed to either $\alpha$-or $\beta$-adrenergic stimulation.

\section{METHODS}

Inbred white Wistar rats of either sex, without any dietary restriction, weighing between 150 and $250 \mathrm{~g}$, were used. The method used was the one described by Vane (1957), with minor modifications. The rats were killed by decapitation and the stomach was removed and cleansed with Tyrode solution at $37^{\circ} \mathrm{C}$. The stomach fundus was halved by carefully cutting in the direction of the longitudinal fibres. Along this incision strips of about $2-3 \mathrm{~mm}$ width and about $2 \mathrm{~cm}$ length were cut. The muscle strip was suspended in a $10 \mathrm{ml}$ organ bath filled with Tyrode solution at $37^{\circ} \mathrm{C}$. The composition of the Tyrode solution
Rat stomach preparation

Indirect action of dopamine was: $\mathrm{KCl} 200 \mathrm{mg}, \mathrm{CaCl}_{2} \cdot 2 \mathrm{H}_{2} \mathrm{O} 200 \mathrm{mg}, \mathrm{Na}_{2} \mathrm{HPO}_{4}$ $10 \mathrm{mg}, \mathrm{MgSO}_{4} \cdot 7 \mathrm{H}_{2} \mathrm{O} 300 \mathrm{mg}, \mathrm{NaHCO}_{3} 1000 \mathrm{mg}$, $\mathrm{NaCl} 7920 \mathrm{mg}$, glucose $1000 \mathrm{mg}$, distilled water 1 liter. 95\% oxygen, 5\% carbon dioxide was bubbled through the organ bath. The Tyrode solution was changed every 15 minutes. Experiments were started after 45 min of equilibration. The free end of the strip was attached to an isotonic lever giving about a 20 -fold magnification. Contractions were recorded on a smoked drum. Single administration of drugs was used instead of a cumulative technique. The following drugs were used: serotonin creatinine sulfate (Boehringer); dopamine $\mathrm{HCl}$ (Fluka); ergotamine tartrate (Gynergen , Sandoz); methysergide = UML (Deser$\mathrm{il}^{\circledR}$, Sandoz); propranolol (Inderal ${ }^{\circledR}$. I.C.I.); isoprenaline (isopropylarterenoli sulfas); noradrenaline $(l$-arterenol - bitartrate - monohydrate, Sigma Co.).

\section{RESULTS}

In 19 out of 22 experiments, dopamine $10^{-7}$ molar produced a contraction of the rat stomach fundus. Offermeier and Ariëns (1966) recommend $\alpha$-adrenergic blockade in comparable experiments, and ergotamine $5 \times 10^{-6}$ molar was therefore added in a new series of experiments. The contractions were potentiated by this procedure (fig. 1). Contractions were found in 79 out 


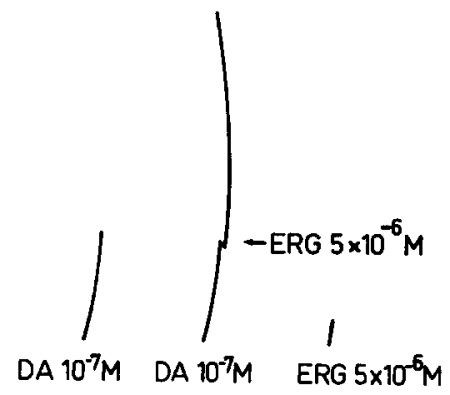

Fig. 1. Effects on the rat stomach preparation of dopamine (DA) $10^{-7} \mathrm{~mol}$, of ergotamine (ERG) $5 \times 10^{-6} \mathrm{~mol}$ in the presence of dopamine $10^{-7} \mathrm{~mol}$, and of ergotamine $5 \times 10^{-6} \mathrm{~mol}$ alone. Time interval $15 \mathrm{~min}$. Ergotamine was added after the dopamine-response was constant for $2 \mathrm{~min}$.

of 83 experiments of this series. If the fundus was repeatedly exposed to dopamine, the contractions became less and tachyphylaxis developed (fig. 2). The dopamine contraction cannot be due to $\alpha$ - or $\beta$-adrenergic stimulation, since both cause relaxation (Vane, 1957; Offermeier and Ariëns, 1966). Identical results were obtained in experiments of this study. Therefore, the effect of dopamine had to be ascribed either to a dopamine receptor or to another non-adrenergic receptor. Accordingly, the interaction of dopamine with 5-HT receptors was investigated. The 5-HT antagonist, UML, in a concentration of $10^{-7}$ molar reduced the dopamine contraction (fig. 3). Because of the tachyphylaxis which developed during repeated exposures to dopamine, the UML was added to the bath while dopamine was still present and at the time of maximal contraction.

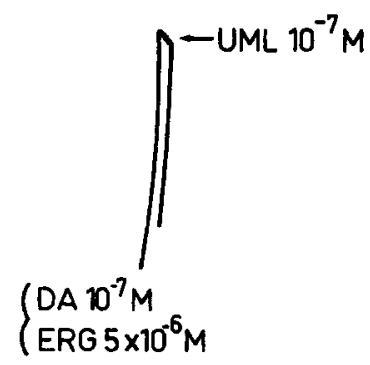

Fig. 3. Effect of UML $10^{-7} \mathrm{~mol}$ on the contraction produced by the combination of dopamine (DA) $10^{-7} \mathrm{~mol}$ and ergotamine (ERG) $5 \times 10^{-6} \mathrm{~mol}$. UML was added after 2 min constant effect.

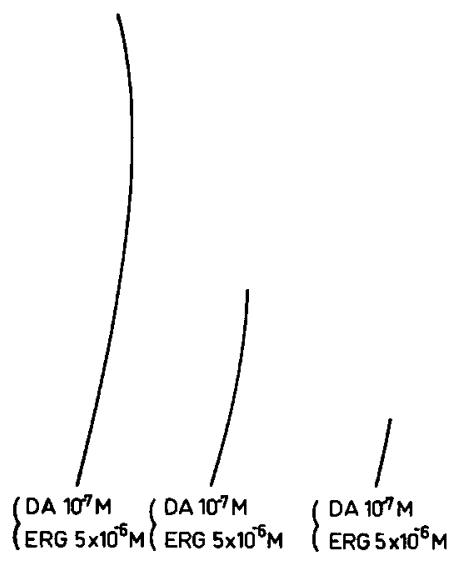

Fig. 2. Effect of repeated administration of a combination of dopamine (DA) $10^{-7} \mathrm{~mol}$ and ergotamine (ERG) $5 \times 10^{-6} \mathrm{~mol}$. Time interval $15 \mathrm{~min}$.

In subsequent experiments the stomach fundus was incubated with 5-HT after tachyphylaxis had occurred. 5-HT caused a contraction and the fundus was exposed for $20 \mathrm{~min}$ to this amine. The 5-HT was then washed out and the sensitivity of the fundus to dopamine was determined again. The stimulating effect of dopamine was completely restored by this procedure (fig. 4). The 5-HT contraction itself was followed by a small, but consistent relaxation. Addition of noradrenaline $10^{-7}$ molar produced further relaxation. This relaxation could be abolished by ergotamine $5 \times 10^{-6}$ molar (fig. 5a). Addition of

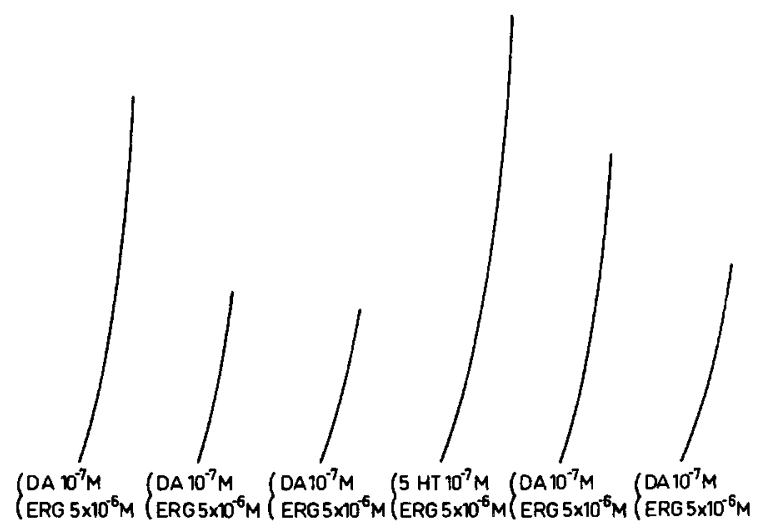

Fig. 4. Effect of preincubation with 5-HT 10-7 mol on the tachyphylaxis to dopamine. Time intervals $15 \mathrm{~min}$. Note: after incubation with 5 -HT for 20 min the sensitivity to dopamine is restored. 


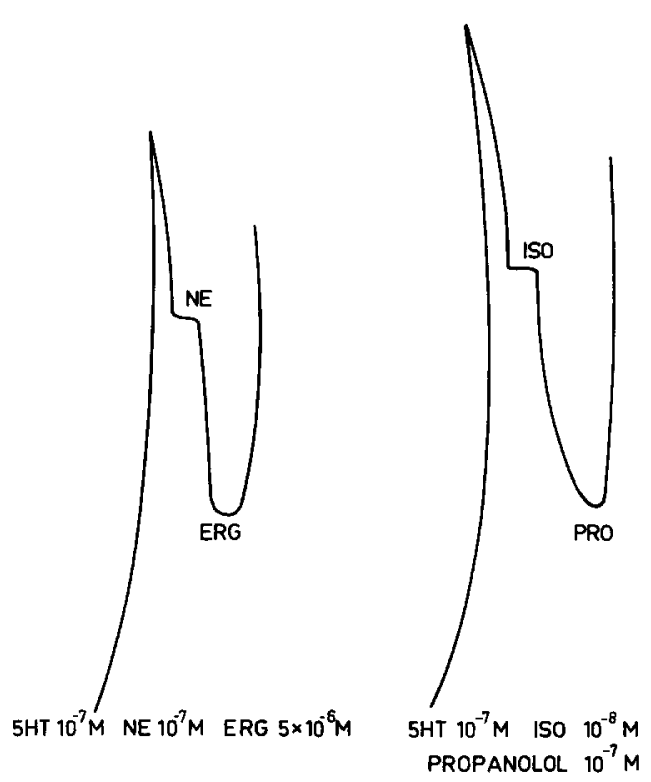

Fig. 5. Contraction of the rat stomach fundus caused by $5-\mathrm{HT} 10^{-7} \mathrm{~mol}$ and the effects on this contraction of a) noradrenaline (NE) $10^{-7} \mathrm{~mol}$ followed by ergotamine (ERG) $5 \times 10^{-6} \mathrm{~mol}$ and of b) isoprenaline (ISO) $10^{-8}$ mol followed by propranolol (PRO) $10^{-7}$ mol. Additions were made after the effects had been constant for $2 \mathrm{~min}$. Two different organs were used in the experiments $a$ and $b$.

isoprenaline $10^{-8}$ molar at the same point, also produced a marked further relaxation. Propranolol 10-7 molar abolished this effect (fig. $5 \mathrm{~b}$ ).

These experiments show that the observed action of dopamine is a phenomenon that is not due to the $\alpha$-or $\beta$-adrenergic properties of this drug.

\section{DISCUSSION}

The results show that dopamine causes a contraction of the rat stomach fundus which is blocked by the 5 -HT antagonist UML. Tachyphylaxis to the dopamine contraction occurred after repeated administration of the amine, but incubation with $5-\mathrm{HT}$ restored the dopamine effect to near initial values. These results disagree with those of Vane (1960) who found that dopamine caused relaxation of the stomach fundus. This difference may be explained by the higher doses used by this author. Another explanation could be that in Vane's experiments endogenous 5-HT had already been washed out completely. The apparent close relationship between dopamine and 5-HT might be caused by their chemical resemblance. The parent amino-acids are decarboxylated by the same enzyme system and the products of this decarboxylation might be regarded as structural analogues. For example, dopamine might be depicted as a folded up indole-like structure resembling 5,6-dihydroxyindole, or dopamine and 5-HT may be regarded as $\beta$-substituted ethylamines. The results suggest that dopamine is acting via $5-\mathrm{HT}$ receptors in the rat stomach preparation. Since tachyphylaxis occurs and the sensitivity to dopamine can be restored with $5-\mathrm{HT}$, the action of dopamine is probably an indirect one in that it liberates 5 HT, which causes the stomach fundus to contract.

These results may contribute to the under standing of the action of dopamine and to the fact that this amine and 5-HT sometimes exhibit identical effects (McDonald and Goldberg, 1963; McCubbin et al., 1962). Further experiments are needed to support the hypothesis that a number of actions of dopamine might be caused indirectly by release of $5-\mathrm{HT}$.

\section{ACKNOWLEDGEMENTS}

We are greatly indebted to Dr. W. G. Mischner (Sandoz) for supplying us with ergotamine tartrate (Gynergen $\left.{ }^{\circledR}\right)$ and UML (Deseril ${ }^{\circledR}$ ).

The technical assistance of Miss Elise Bettink is gratefully acknowledged.

\section{REFERENCES}

Eble, J.N., 1964, A proposed mechanism for the depressor effect of dopamine in the anesthetized dog, J. Pharmacol. Exp. Ther. 111, 265.

Ernst, A.M., 1965, Relation between the action of dopamine and apomorphine and their O-methylated derivatives upon the CNS, Psychopharmacologia (Berlin) 7, 391.

Goldberg, L. I. and A. Sjoerdsma, 1959, Effects of several monoamine oxidase inhibitors on the cardiovascular actions of naturally occurring amines in the dog, J. Pharmacol. Exp. Ther. 127, 212.

McCubbin, J.W., Y. Kaneko and I. H. Page, 1962, Inhibition of neurogenic vasoconstriction by serotonin: vasodilator action of serotonin, Circulation Res. 11, 74 .

McDonald, R.H. and L. I. Goldberg, 1963, Analysis of the cardiovascular effects of dopamine in the dog, J. Pharmacol. Exp. Ther. 140, 60.

Offermeier, J. and E.J.A riëns, 1966, Serotonin. I. Receptors involved in its action, Arch. Int. Pharmacodyn. $164,192$. 
Vane, J.R., 1957, As sensitive method for the assay of 5-hydroxytryptamine, Brit. J. Pharmacol. 12, 344.

Vane, J.R., 1960, The actions of sympathomimetic amines on tryptamine receptors, in: Ciba Found. Symp. on adrenergic mechanisms, eds. J. R. Vane,
G. E.W. Westenholme and M. O'Connor (J. and A. Churchill Ltd., London) p. 356.

Van Rossum, J. M., 1964, Mechanism of action of psychomotor drugs, Int. J. Neuropharmacol. 3, 227. 